\title{
SYNTHESIS, CHARACTERISATION AND ANTIMICROBIAL ACTIVITIES OF COBALT(II), COPPER(II) AND ZINC(II) MIXED-LIGAND COMPLEXES CONTAINING 1,10-PHENANTHROLINE AND 2,2'-BIPYRIDINE
}

\author{
M.O. Agwara ${ }^{1 *}$, P.T. Ndifon ${ }^{1}$, N.B. Ndosiri ${ }^{1}$, A.G. Paboudam ${ }^{1}$, D.M. Yufanyi ${ }^{2}$ and \\ A. Mohamadou ${ }^{3}$ \\ ${ }^{1}$ Coordination Chemistry Laboratory, Department of Inorganic Chemistry, Faculty of Science, \\ University of Yaoundé I, P.O. Box 812, Yaoundé, Cameroun \\ ${ }^{2}$ Department of Chemistry, University of Buea, P.O. Box 63, Buea, Cameroun \\ ${ }^{3}$ Institut de Chimie Moléculaire de Reims CNRS UMR 6229, Groupe de Chimie de \\ Coordination, Faculté des Sciences, Université de Reims Champagne, Ardenne, France
}

(Received September 4, 2009; revised March 17, 2010)

\begin{abstract}
Three new 1,10-phenanthroline and 2,2'-bipyridine mixed-ligand complexes of $\left[\mathrm{Co}(\right.$ bpy $\left.\left.)(\text { phen })_{2}\right]\left(\mathrm{NO}_{3}\right)_{2} \cdot 2 \mathrm{H}_{2} \mathrm{O}, \quad\left[\mathrm{Cu}(\text { bpy })(\text { phen }) \quad \mathrm{H}_{2} \mathrm{O}\right)_{2}\right] \mathrm{Cl}_{2} \cdot 2 \mathrm{H}_{2} \mathrm{O}, \quad$ and $\quad\left[\mathrm{Zn}(\text { bpy })_{2}(\right.$ phen $\left.)\right] \mathrm{Cl}_{2} \cdot 6 \mathrm{H}_{2} \mathrm{O}$ were synthesized. The complexes were characterized by elemental, IR and visible spectroscopic analyses and the results indicate that both ligands are coordinated to the respective metal ions giving octahedral complexes. Antimicrobial studies showed that there is increased antimicrobial activity of the metal ions on coordination to the ligands. The water soluble complexes showed antimicrobial activities that are higher than those of the metal salts and 2,2'bipyridine but lower than those of 1,10-phenanthroline. The copper complex $\left[\mathrm{Cu}(\mathrm{bpy})(\mathrm{phen})\left(\mathrm{H}_{2} \mathrm{O}\right)_{2}\right] \mathrm{Cl}_{2} \cdot 2 \mathrm{H}_{2} \mathrm{O}$
\end{abstract} shows the highest activity.

KEY WORDS: 1,10-Phenanthroline, 2,2'-Bipyridine, Mixed-ligand complexes, Antimicrobial activities, Cobalt(II), Copper(II), Zinc(II)

\section{INTRODUCTION}

Many metal ions are known to play very important roles in biological processes in the human body [1, 2]. For example, zinc(II) and copper(II) ions are the second and third most abundant transition metals in humans. They are found either at the active sites or as structural components of a good number of enzymes [3,4]. The main biochemical role of cobalt in biological systems is its involvement in vitamin $\mathrm{B}_{12}$, a co-enzyme in some biochemical processes [3]. These metals and some of their complexes have been found to exhibit antimicrobial activities [5-7]. The ligands, 1,10-phenanthroline (phen) and 2,2'-bipyridine (bpy) are strong field bidentate ligands that form very stable chelates with many first row transition metals [8]. These ligands, as well as some of their derived complexes, do exhibit antimicrobial properties [9, 10]. A number of transition metal mixed-ligand complexes containing 1,10-phenanthroline or 2,2'-bipyridine and other ligands such as Schiff bases derived from amino acids [11-14], oxydiacetate [15], diethylenetetramine [16, 17], oxalate [18] and halides, $\mathrm{X}(\mathrm{X}=\mathrm{Cl}, \mathrm{Br}, \mathrm{I})$ [19] have been reported in the literature.

Although a good number of metal mixed-ligand complexes containing either 2,2'-bipyridine or 1,10-phenanthroline with some other ligands are reported in the literature, to our knowledge, there are a few reports on the synthesis and biological activities of metal mixed-ligand complexes containing 2,2'-bipyridine and 1,10-phenanthroline as ligands [20].

We report here in the synthesis, characterisation and biological activities of the new cobalt(II), copper(II), and zinc(II) mixed-ligand complexes containing 1,10-phenanthroline and 2,2'-bipyridine as ligands. The synthesized complexes are characterised by elemental, IR and visible spectroscopic analyses.

*Corresponding author. E-mail: agwara29@yahoo.com; Tel. 23779875425 


\section{EXPERIMENTAL}

\section{Materials}

Commercial reagents were used as obtained without further purification. $\mathrm{Co}\left(\mathrm{NO}_{3}\right)_{2} \cdot 6 \mathrm{H}_{2} \mathrm{O}$, $\mathrm{ZnCl}_{2}$, 1,10-phenanthroline, and 2,2'-bipyridine were purchased from Riedel-de Haën (Germany), while $\mathrm{CuCl}_{2} 2 \mathrm{H}_{2} \mathrm{O}$ was purchased from Labosi (France). The solvents ethanol and diethylether were dried and distilled according to standard methods. The bacteria strains were obtained from Centre Pasteur, Yaoundé, Cameroun.

\section{Physical measurements}

Elemental analyses for carbon, nitrogen, and hydrogen were carried out on a Fisons Instrument 1108 CHNS-O (France), while cobalt(II), copper(II), and zinc(II) were quantitatively estimated by complexometric titrations [21]. Infrared (IR) spectra of solid samples as $\mathrm{KBr}$ pellets were recorded on a Perkin-Elmer model IR-457 spectrophotometer (France) and a Spectrum 100 FTIR Perkin-Elmer spectrophotometer (France), while electronic absorption spectra of samples dissolved in ethanol were recorded on a Hitachi U-2000 spectrophotometer (France).

Synthesis

Generally, the complexes were prepared by reacting the respective metal salts with the ligands using 1:1:2 mole ratio, i.e. one mole of metal salt : one mole of 2,2'-bipyridine : two moles of 1,10-phenanthroline. For example, $\left[\mathrm{Co}(\mathrm{bpy})(\mathrm{phen})_{2}\right]\left(\mathrm{NO}_{3}\right)_{2} \cdot 2 \mathrm{H}_{2} \mathrm{O}$ was prepared by adding dropwise a solution of 1,10-phenanthroline $(0.72 \mathrm{~g}, 4.0 \mathrm{mmol})$ in $15 \mathrm{~mL}$ of ethanol to a solution of $\mathrm{Co}\left(\mathrm{NO}_{3}\right)_{2} 6 \mathrm{H}_{2} \mathrm{O}(0.31 \mathrm{~g}, 2.0 \mathrm{mmol})$ in $10 \mathrm{~mL}$ of water while stirring magnetically at room temperature. A reddish homogeneous solution was obtained. To the above homogenous solution was added 2,2'-bipyridine $(0.31 \mathrm{~g}, 2.0 \mathrm{mmol})$ in $12 \mathrm{~mL}$ of ethanol dropwise while still stirring. Stirring was continued for one more hour and the resulting solution allowed to stand for four days during which time pale red crystals were observed to form. During five additional days, sufficient crystals were formed and these were filtered, washed with diethylether and dried in vacuo. Yield was $20 \%$, m.p. $>250{ }^{\circ} \mathrm{C}$. Elemental analysis calculated for $\mathrm{C}_{34} \mathrm{H}_{28} \mathrm{CoN}_{8} \mathrm{O}_{8}(\%)$ : C 55.51, H 3.84, N 15.23; found (\%): C 55.40, H 3.71, N 14.90; characteristic IR bands, $\mathrm{v} / \mathrm{cm}^{-1}$ : 1588 (bpy), $1446\left(v_{\mathrm{C}=\mathrm{C}}\right.$, phen $), 726\left(v_{\mathrm{C}-\mathrm{H}}\right.$, phen $), 446\left(v_{\mathrm{Co-N}}\right)$; visible bands, $\lambda_{\max }: \mathrm{cm}^{-1}(\varepsilon / \mathrm{L}$ $\left.\mathrm{cm}^{-1} \mathrm{~mol}^{-1}\right)$ : 19763 (7.2). The other compounds were similarly synthesized.

$\left[\mathrm{Cu}\left(\right.\right.$ bpy) (phen) $\left.\left(\mathrm{H}_{2} \mathrm{O}\right)_{2}\right] \mathrm{Cl}_{2} \cdot 2 \mathrm{H}_{2} \mathrm{O}$ was obtained as green-blue crystals with yield of $28 \%$, m.p. $>250{ }^{\circ} \mathrm{C}$. Elemental analysis calculated for $\mathrm{C}_{22} \mathrm{H}_{24} \mathrm{CuN}_{4} \mathrm{Cl}_{2} \mathrm{O}_{4}(\%)$ : C 48.66, $\mathrm{H} 4.46, \mathrm{~N}$ 10.32; found (\%): C 48.95, H 4.26, N 9.93; characteristic IR bands, v/cm ${ }^{-1}: 1660\left(\mathrm{H}_{2} \mathrm{O}\right), 1587$ (bpy), $1436\left(v_{\mathrm{C}=\mathrm{C}}\right.$, phen $), 724\left(\mathrm{v}_{\mathrm{C}-\mathrm{H}}\right.$, phen $), 641\left(\mathrm{v}_{\mathrm{Cu}-\mathrm{O}}\right)$ and $\left(479\left(\mathrm{v}_{\mathrm{Cu}-\mathrm{N}}\right)\right.$; visible bands, $\lambda_{\max }: \mathrm{cm}^{-1}$ $\left(\varepsilon / \mathrm{Lcm}^{-1} \mathrm{~mol}^{-1}\right): 13966(6.3)$.

$\left[\mathrm{Zn}(\text { bpy })_{2}(\right.$ phen $\left.)\right] \mathrm{Cl}_{2} \cdot 6 \mathrm{H}_{2} \mathrm{O}$ was obtained as cream-white crystals with yield $47 \%$, m.p. $>250$ ${ }^{\circ} \mathrm{C}$. Elemental analysis calculated for $\mathrm{C}_{32} \mathrm{H}_{36} \mathrm{ZnN}_{6} \mathrm{Cl}_{2} \mathrm{O}_{6}(\%)$ : C 52.14, $\mathrm{H}$ 4.90, N 11.40; found (\%): C 52.83, H 4.55, N 11.85; characteristic IR bands, v/cm ${ }^{-1}: 1587$ (bpy), 1436 ( $v_{\mathrm{C}=\mathrm{C}}$,phen), $725\left(v_{\mathrm{C}-\mathrm{H}}, \mathrm{phen}\right), 469\left(\mathrm{v}_{\mathrm{Zn}-\mathrm{N}}\right)$.

\section{Anti-microbial tests}

The antimicrobial tests were carried out in the Applied Microbiology and Molecular Pharmacology Laboratory of the University of Yaoundé I. 
Nine species of microorganisms Enterobacter cloacae, Morganella morganii, Shigella flexneri, Salmonella typhi, Klebsiella pneumoniae, Citrobacter freundii, Escherichia coli, Pseudomonas aeruginosa and Staphylococcus aureus used for this study were provided by 'Centre Pasteur du Cameroun', Yaoundé. The microbial isolates were maintained on agar slant at $4{ }^{\circ} \mathrm{C}$ in the Laboratory of Applied Microbiology and Molecular Pharmacology (LMP), University of Yaoundé I where the antimicrobial tests were performed. The strains were subcultured on fresh appropriate agar plate in incubators 18 hours prior to any antimicrobial test.

Nutriment agar (NA) containing Bromocresol Purple was used for the activation of Bacillus species while NA alone was used for the other bacteria. The Colombia agar medium (CAM) was used for the diffusion assays determination. In vitro antibacterial and antifungal activities of the ligands and complexes were evaluated by the well-diffusion method. Muller-Hinton broth was used as microbial growth medium.

\section{Diffusion test}

The antimicrobial diffusion tests were carried out as described by Berghe and Vlietink [22] using a cell suspension of about $1.5 \times 10^{6} \mathrm{CFU} / \mathrm{mL}$ obtained from the McFarland turbidity Standard No 0.5 . The suspension was standardised by adjusting the optical density to 0.1 at 600 $\mathrm{nm}$ (SHIMADZU UV-120-01 spectrophotometer). The suspension was used for inoculation by floating the surface of the CAM plates. When the excess liquid was allowed to dry under an aspirator hood, holes of 6-mm diameter were made in the medium and filled with $60 \mu \mathrm{L}$ of test samples. Holes with methanol were used as negative control. The plates were inoculated at 37 ${ }^{\circ} \mathrm{C}$ for 24 hours. Antimicrobial activity was evaluated by measuring the diameter of the inhibition zone (IZ) around the hole. The assay was repeated thrice and results recorded as mean \pm standard deviation of triplicated experiments. Compounds were considered as active when the IZ was greater than $6 \mathrm{~mm}$.

\section{RESULTS AND DISCUSSION}

Elemental analyses of the mixed-ligand complexes indicate that one mole of cobalt nitrate reacted with two moles of 1,10-phenanthroline and one mole of 2,2'-bipyridine giving the complex $\left[\mathrm{Co}(\right.$ bpy $\left.)(\text { phen })_{2}\right]\left(\mathrm{NO}_{3}\right)_{2} 2\left(\mathrm{H}_{2} \mathrm{O}\right)$ whose complex ion is similar to $\left[\mathrm{Co}(\mathrm{phen})_{3}\right]^{2+}[23]$ or to $\left[\mathrm{Ru}(\mathrm{bpy})_{3}\right]^{3+}[24]$. On the other hand, one mole of copper(II) chloride reacted with one mole of 1,10-phenanthroline and one mole of 2,2'-bipyridine giving the complex, $\left[\mathrm{Cu}\right.$ (bpy)(phen) $\left.\left(\mathrm{H}_{2} \mathrm{O}\right)_{2}\right] \mathrm{Cl}_{2} \cdot 2 \mathrm{H}_{2} \mathrm{O}$ while one mole of zinc chloride reacted with one mole of 1,10 phenanthroline and two moles of 2,2'-bipyridine giving the complex, $\left[\mathrm{Zn}(\text { bpy })_{2}(\mathrm{phen})\right](\mathrm{Cl})_{2} \cdot 6\left(\mathrm{H}_{2} \mathrm{O}\right)$. The elemental analytical results are close to the theoretical values indicating the presence of both ligands in the complexes. The yields for the complexes range between 20 and $47 \%$. These are low probably due to incomplete crystallisation. The metalmixed ligand complexes which are crystalline solids are very stable in air whereas the starting metal salts are hygroscopic in nature. All the complexes did not melt within the $50-260{ }^{\circ} \mathrm{C}$ range of the Leica VmHB (Koffler's system) melting point apparatus. However, the melting points of 1,10-phenanthroline and 2,2'-bipyridine which are 70 and $97{ }^{\circ} \mathrm{C}$, respectively, are the same as literature values [25]. The complexes are different in colour from the starting metal salts from which they were derived. For example, $\left[\mathrm{Cu}(\right.$ bpy $)($ phen $\left.)\left(\mathrm{H}_{2} \mathrm{O}\right)_{2}\right] \mathrm{Cl}_{2} 2 \mathrm{H}_{2} \mathrm{O}$ is green-blue while the starting copper(II) chloride is deep blue in colour.

In the infrared spectra of the complexes, the band due to ring vibrations of the uncoordinated 2,2'-bipyridine observed at $1621 \mathrm{~cm}^{-1}$ was shifted to $1588 \mathrm{~cm}^{-1}$ in the complexes. This shift by $33 \mathrm{~cm}^{-1}$ to a lower frequency shows that 2,2'-bipyridine is coordinated to the metal centres [12]. Similarly, in the IR spectra of the complexes, the $\mathrm{C}-\mathrm{H}$ and $\mathrm{C}=\mathrm{C}$ stretching bands 
undergo a coordination-induced lower frequency shift of $12 \mathrm{~cm}^{-1}$ and $18 \mathrm{~cm}^{-1}$, respectively [11]. The band observed at $479-446 \mathrm{~cm}^{-1}$ has been assigned to $v_{\mathrm{M}-\mathrm{N}}$ [26]. In the IR spectrum of the copper complex, the bands observed at $1660 \mathrm{~cm}^{-1}$ and $641 \mathrm{~cm}^{-1}$ are assigned to $\mathrm{v}_{\mathrm{H} 2 \mathrm{O}}$ and $\mathrm{v}_{\mathrm{Cu}-\mathrm{O}}$, respectively $[27,28]$. The observed shifts in band positions are a clear indication that both ligands are coordinated to the respective metal centres.

In the visible region, the bands at $19763 \mathrm{~cm}^{-1}$ with an extinction coefficient of $7.2 \mathrm{~L}$ $\mathrm{cm}^{-1} \mathrm{~mol}^{-1}$ for the pale-red $\left[\mathrm{Co}(\mathrm{bpy})(\text { phen })_{2}\right]\left(\mathrm{NO}_{3}\right)_{2} 2\left(\mathrm{H}_{2} \mathrm{O}\right)$ complex is typical of a d-d transition [28]. In an octahedral field, the three spin-allowed electronic transitions are ${ }^{4} T_{1 g}(F) \rightarrow{ }^{4} T_{2 g}$, ${ }^{4} \mathrm{~T}_{1 \mathrm{~g}}(\mathrm{~F}) \rightarrow{ }^{4} \mathrm{~A}_{2 \mathrm{~g}}$ and ${ }^{4} \mathrm{~T}_{1 \mathrm{~g}}(\mathrm{~F}) \rightarrow{ }^{4} \mathrm{~T}_{1 \mathrm{~g}}(\mathrm{P})$. The above observed band has been assigned to ${ }^{4} \mathrm{~T}_{1 \mathrm{~g}}(\mathrm{~F}) \rightarrow$ ${ }^{4} \mathrm{~A}_{2 \mathrm{~g}}[28,29]$. This band is different from that of $\left[\mathrm{Co}(\mathrm{bpy})_{3}\right]^{2+}$ at $22000 \mathrm{~cm}^{-1}$ [4]. Copper(II) six co-ordinate complexes are usually blue-green in colour because of the single broad absorption band in the region 11000-16000 $\mathrm{cm}^{-1}$ [30]. In the visible spectrum of the blue-green complex $\left[\mathrm{Cu}\right.$ (bpy)(phen) $\left.\left(\mathrm{H}_{2} \mathrm{O}\right)_{2}\right] \mathrm{Cl}_{2} 2 \mathrm{H}_{2} \mathrm{O}$, this unsymmetrical broad band at $13966 \mathrm{~cm}^{-1}$ with a typical extinction coefficient of $6.25 \mathrm{Lcm}^{-1} \mathrm{~mol}^{-1}$ has therefore been assigned to the ${ }^{2} \mathrm{E}_{\mathrm{g}} \rightarrow{ }^{2} \mathrm{~T}_{\mathrm{g}}$ transition [29]. Usually, zinc(II) complexes are white in colour but the complex $\left[\mathrm{Zn}(\text { bpy })_{2}(\right.$ phen $\left.)\right](\mathrm{Cl})_{2} 6\left(\mathrm{H}_{2} \mathrm{O}\right)$ is cream in colour due metal-ligand charge transfer [31]. The proposed structures of these complexes are presented in Figure 1. These will be confirmed by subsequent $\mathrm{X}$-ray analysis.

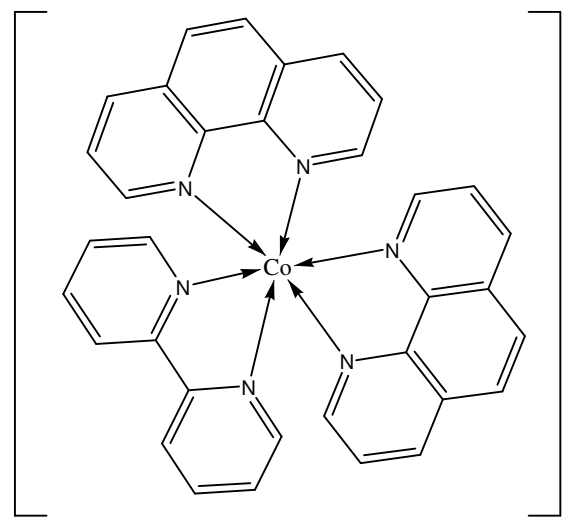

$\left(\mathrm{NO}_{3}\right)_{2} \cdot 2 \mathrm{H}_{2} \mathrm{O}$

$\left[\mathrm{Co}(\right.$ bpy $\left.)(\text { phen })_{2}\right]\left(\mathrm{NO}_{3}\right)_{2} \cdot 2 \mathrm{H}_{2} \mathrm{O}$

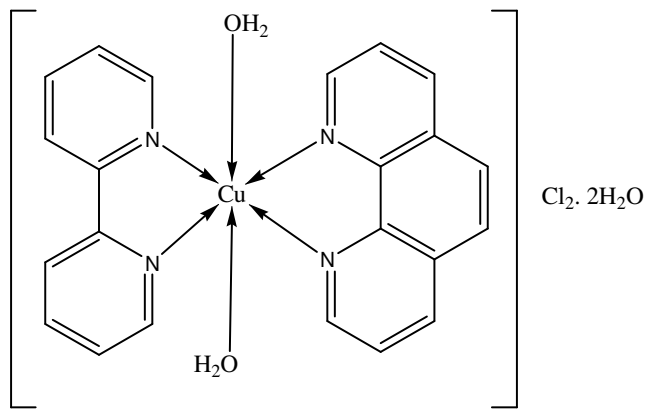

$\left[\mathrm{Cu}(\right.$ bpy $)($ phen $\left.)\left(\mathrm{H}_{2} \mathrm{O}\right)_{2}\right] \mathrm{Cl}_{2} \cdot 2 \mathrm{H}_{2} \mathrm{O}$

Bull. Chem. Soc. Ethiop. 2010, 24(3) 


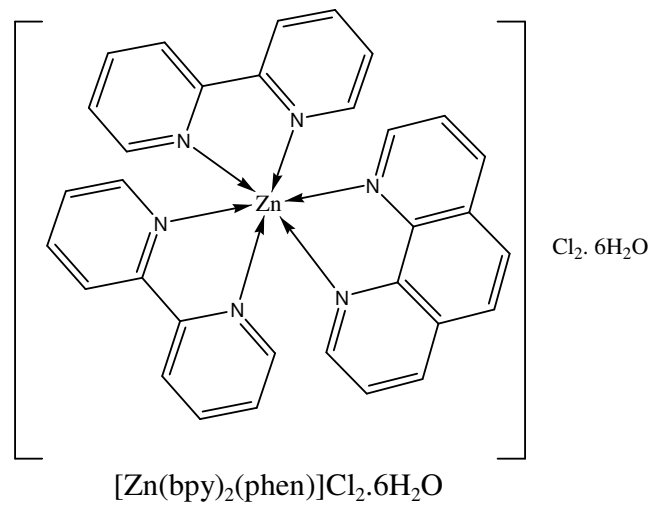

Figure 1. Proposed structures of the complexes.

\section{Anti-microbial tests}

The ligands, metal salts and metal mixed-ligand complexes were tested for antimicrobial activities against nine bacteria obtained from the Centre Pasteur, Yaoundé, Cameroun. These tests were carried out in the Department of Biochemistry, University of Yaoundé I, Cameroun. The results of the susceptibility of these bacterial strains towards the compounds, judged by measuring the inhibition zone growth diameter (IZ), are presented in Table 1.

Table 1. Antimicrobial activities of the ligands, metal salts and metal mixed-ligand complexes.

\begin{tabular}{|l|c|c|c|c|c|c|c|c|c|}
\hline \multirow{2}{*}{ Bacteria } & \multicolumn{7}{|c|}{ Antimicrobial activity (IZ diameter in mm) } \\
\cline { 2 - 12 } & 1 & 2 & 3 & 4 & 5 & 6 & 7 & 8 & RA \\
\hline Enterobacter choacae & 32 & -- & 11 & 22 & -- & 30 & 9 & 18 & 28 \\
\hline Staphylococcus aureus & 31 & 9 & 10 & 24 & 7 & 30 & 8 & 20 & 30 \\
\hline Escherichia coli & 31 & 14 & 13 & 22 & 8 & 29 & 9 & 22 & 22 \\
\hline Morganella morganii & 30 & -- & 11 & 23 & -- & 29 & -- & 20 & 27 \\
\hline Salmonella thyphi & 32 & 9 & 12 & 25 & -- & 31 & 9 & 17 & 30 \\
\hline Klebsiella pneumoniae & 28 & -- & 11 & 20 & 7 & 26 & 10 & 17 & 29 \\
\hline Shigella flexineri & 31 & 13 & 13 & 22 & 8 & 30 & 10 & 20 & 22 \\
\hline Citrobacter freundi & 30 & 10 & -- & 16 & -- & 26 & -- & 16 & 21 \\
\hline Pseudomonas aeruginosa & 31 & 7 & 11 & 23 & -- & 30 & 10 & 19 & 25 \\
\hline
\end{tabular}

$\mathrm{IZ}=$ inhibition zone; $1=1,10$-phenanthroline (phen); $2=2,2^{\prime}$-bipyridine (bpy); $3=\mathrm{Co}\left(\mathrm{NO}_{3}\right)_{3} 6 \mathrm{H}_{2} \mathrm{O} ; 4=$ $\left[\mathrm{Co}(\right.$ bpy $\left.)(\text { phen })_{2}\right]\left(\mathrm{NO}_{3}\right)_{2} 2 \mathrm{H}_{2} \mathrm{O} ; 5=\mathrm{CuCl}_{2} 2 \mathrm{H}_{2} \mathrm{O} ; \quad 6=[\mathrm{Cu}($ bpy $)($ phen $)] \mathrm{Cl}_{2} 2 \mathrm{H}_{2} \mathrm{O} ; \quad 7=\mathrm{ZnCl}_{2} ; 8=$ $\left[\mathrm{Zn}(\text { bpy })_{2}(\right.$ phen $\left.)\right] \mathrm{Cl}_{2} 6 \mathrm{H}_{2} \mathrm{O} ; \mathrm{RA}=$ reference antibiotics (gentamycin).

The ligand 1,10-phenanthroline exhibited the greatest antimicrobial activities (9/9) with high inhibition zones ranging from $28 \mathrm{~mm}$ to $32 \mathrm{~mm}$ while 2,2-bipyridine exhibited selective antimicrobial activities (6/9) against the pathogens with lower inhibition zones ranging between 7 and $14 \mathrm{~mm}$. The metal salts also showed a selective effect on the tested organisms in the order $\mathrm{Co}\left(\mathrm{NO}_{3}\right)_{2} \cdot 6 \mathrm{H}_{2} \mathrm{O}(8 / 9)>\mathrm{ZnCl}_{2} \cdot 6 \mathrm{H}_{2} \mathrm{O}(7 / 9)>\mathrm{CuCl}_{2} \cdot 6 \mathrm{H}_{2} \mathrm{O}(4 / 9)$. The IZ values for cobalt nitrate $(10-13 \mathrm{~mm})$ are greater than those for copper and zinc chlorides $(7-10 \mathrm{~mm})$. All the metal-mixed ligand complexes are active against all (9/9) tested organisms with IZ values of 16-31 mm. These values are lower than those for free phenanthroline and higher than those for free bipyridine ligands. Therefore the metal complexes show greater antimicrobial activities than the 
uncoordinated ligand and free metal ion which in fact is in agreement with the literature [32]. These mixed-ligand complexes have an advantage in that the respective bioactivities of the uncoordinated ligands and metal ions are combined which could make them more potent antimicrobial agents. The water soluble complexes enable them to be applied in humans since water is the main component of the human body. The copper-mixed ligand complex showed the greatest activity, the zinc-mixed ligands complex showed the lowest activity. In order of increasing activity, we have $[\mathrm{Cu}($ bpy $)($ phen $)](\mathrm{Cl})_{2} \cdot 4\left(\mathrm{H}_{2} \mathrm{O}\right)>\left[\mathrm{Co}(\right.$ bpy $\left.)(\text { phen })_{2}\right]\left(\mathrm{NO}_{3}\right)_{2} 2 \mathrm{H}_{2} \mathrm{O}>$ $\left[\mathrm{Zn}(\mathrm{bpy})_{2}(\mathrm{phen})\right] \mathrm{Cl}_{2} \cdot 6 \mathrm{H}_{2} \mathrm{O}$. The very high antimicrobial activities of the copper complex, $[\mathrm{Cu}$ (bpy)(phen) $] \mathrm{Cl}_{2} \cdot 2 \mathrm{H}_{2} \mathrm{O}$ and the cobalt complex, $\left[\mathrm{Co}(\right.$ bpy $\left.)(\text { phen })_{2}\right]\left(\mathrm{NO}_{3}\right)_{2} \cdot 2 \mathrm{H}_{2} \mathrm{O}$ could be further studied for the treatment of infections caused by any of the above organisms.

\section{CONCLUSIONS}

Metal-mixed ligand complexes of cobalt(II), copper(II), and zinc(II) containing 1,10phenanthroline and 2,2'-bipyridine as ligands have been synthesised and characterised by elemental, IR and visible spectroscopy analyses. While two molecules of 1,10-phenanthroline and one molecule of 2,2'-bipyridine are coordinated to cobalt(II) giving a six-coordinate complex ion $\left[\mathrm{Co}(\text { bpy })(\text { phen })_{2}\right]^{2+}$, one molecule each of the ligands and two water molecules coordinate to copper(II) and zinc(II) is coordinated to two molecules of 2,2'-bipyridine and one molecule of 1,10-phenanthroline. Antimicrobial studies of these complexes against nine bacteria show that there is increased activity of the metal ions upon coordination to these ligands. There is a decrease in the activities of 1,10-phenanthroline as well as an increase in the case of 2,2'bipyridine upon coordination. The activity order is $\left[\mathrm{Cu}(\right.$ bpy $)($ phen $\left.)\left(\mathrm{H}_{2} \mathrm{O}\right)_{2}\right](\mathrm{Cl})_{2} \cdot 2\left(\mathrm{H}_{2} \mathrm{O}\right)>$ $\left[\mathrm{Co}(\right.$ bpy $\left.)(\text { phen })_{2}\right]\left(\mathrm{NO}_{3}\right)_{2} 2 \mathrm{H}_{2} \mathrm{O}>\left[\mathrm{Zn}(\text { bpy })_{2}(\right.$ phen $\left.)\right] \mathrm{Cl}_{2} 6 \mathrm{H}_{2} \mathrm{O}$. The very high antimicrobial activities of the copper complex, $[\mathrm{Cu}(\mathrm{bpy})(\mathrm{phen})] \mathrm{Cl}_{2} 2 \mathrm{H}_{2} \mathrm{O}$ and the cobalt complex, $\left[\mathrm{Co}(\mathrm{bpy})(\text { phen })_{2}\right]\left(\mathrm{NO}_{3}\right)_{2} \cdot 2 \mathrm{H}_{2} \mathrm{O}$ could be further studied for the treatment of infections caused by any of the organisms studied.

\section{AKNOWLEDGEMENTS}

We thank the ATER programme (PGA) of the University of Yaoundé I, Cameroun for financial assistance.

\section{REFERENCES}

1. Kaim, W.; Schwederski, B. Bioinorganic Chemistry: Inorganic Elements of Life, John Wiley and Sons: London; 1996; pp 39-262.

2. Xiao-Ming, C.; Bao-Hui, Y.; Xiao, C.H.; Zhi-Tao, X. J. Chem. Soc., Dalton Trans. 1996, 3465.

3. Cotton, F.A.; Wilkinson G. Advanced Inorganic Chemistry, 5th ed., John Wiley and Sons: New York; 1988; pp 1358-1371.

4. Greenwood, N.N.; Earnshaw, A. Chemistry of the Elements, Pergamon Press: Oxford, 1984; pp 1392-1420.

5. Faundez, G.; Troncoso, M.; Navarette, P.; Figueroa, G. BMC Microbiol. 2004, 4, 1471.

6. Khan, F.; Patoare, Y.; Karim, P.; Rayhan, I.; Quadir, M.A.; Hasna, A. Pak. J. Pharm. 2005, 18, 57.

7. Baena, M.I.; Marquez, M.C.; Matres, V.; Botella, J.; Ventosa, A. Curr. Microbiol. 2006, $53,491$.

8. Lee, J.D. Concise Inorganic Chemistry, 4th ed., Chapman and Hall: London; 1991; pp 6071074. 
Synthesis and antimicrobial activities of $\mathrm{Co}(\mathrm{II}), \mathrm{Cu}(\mathrm{II})$ and $\mathrm{Zn}(\mathrm{II}))$ mixed-ligand complexes 389

9. Coyle, B.; Kwanagh, K.; Mcxcann, M.; Devereux, M.; Geraghty, M. Biometals 2003, 16, 1572.

10. Bapna, M.S.; Mukherjee, S.; Murphy, R. J. Oral Rehabit. 2007, 19, 111.

11. Bonghaei, D.M.; Gharagozlou, M. Spectrochim. Acta Part A 2007, 67, 944.

12. Reddy, P.A.N.; Nethaji, M.; Chakravarty, A.R. Inorg. Chim. Acta 2002, 337, 450.

13. Marc, S.; Larisa, E.; Kapinos, B.; Lippert, B.; Sigel, H. J. Chem. Soc., Dalton Trans. 1999, 357.

14. Milani, B.; Alesio, E.; Mestron, G.; Sommazzi, A. J. Chem. Soc., Dalton Trans. 1977, 1571.

15. Baggio, R.; Garland, M.; Perec, M. J. Chem. Soc., Dalton Trans. 1996, 2747.

16. Patel, R.N.; Singh, N.; Shukka, K.K.; Chauhan, U.K.; Niclos-Gutierrez, J.; Castineiras, A. Inorg. Chim. Acta 2004, 377, 2469.

17. Patel, R.N.; Singh, N.; Shukka, K.K.; Niclos-Gutierrez, J.; Castineiras, A.; Vaidyanathan, V.G.; Nair, B.U. Spectrochim. Acta Part A 2005, 62, 261.

18. Carmen, M.M.; Miguel, J.; Francesc, L.; Andruh, M., J. Chem. Soc., Dalton Trans. 1998, 3125.

19. Mrinal, M.; Ghosh, P.; Bhattacharya, R. J. Chem. Soc., Dalton Trans. 1993, 1731.

20. Hazel, A.; Simonsen, O.; Wernberg, O. Acta. Cryst. 1986, C42, 1707.

21. Harris, D.C. Quantitative Chemical Analysis, 3rd ed., W.H. Freeman: New York; 1991; pp 279-299.

22. Berghe, V.A.; Vlietinck, A.J. Methods Plant Biochem. 1991, 6, 47.

23. Purcel, K.F.; Kotz, J.C. Inorganic Chemistry, WB Saunders Company: Philadelphia; 1997; p 663.

24. Nicolas, C.F.; Nieuwenhuyzen, M.; Rainey, S. J. Chem. Soc., Dalton Trans. 2001, 2641.

25. Weast, R.C.; Astle, M.J.; Beyer, W.H., Handbook of Chemistry and Physics, CRC Press Inc.: Boca Raton, Florida; 1985-1986.

26. Pessoa, J.C.; Covcia, I.; Correia, I.; Duarte, M.T.; Gillard, R.D.; Henriques, R.T.; Higes, F.J.; Madeira, C.; Tomaz, I. Inorg. Chim. Acta 1999, 293, 1.

27. Agwara, M.O.; Ndifon, P.T.; Ndikontar, M.K. Bull. Chem. Soc. Ethiop. 2004, 18, 143.

28. Ndifon, P.T.; Agwara, M.O.; Paboudam, A.G.; Yufanyi, D.M.; Ngoune, J.; Galindo, A.; Alvarez, E.; Hohamadou, A. Transition Met. Chem. 2009, 34, 745.

29. Nicholis, D. Complexes and First Row Transition Elements, The Macmillan Press: G. Britain; 1979; pp. 52.

30. Allan, J.R.; Brown, D.H.; Lappin, M. J. Inorg. Nucl. Chem. 1970, 32, 2287.

31. Nagababu, P.; Naveena, L.L.; Pallavi, P.; Harris, S.; Satyanarayana, S. Can. J. Microbiol. 2006, 15, 1247.

32. Agwara, M.O.; Ndifon, P.T.; Ndikontar, M.K.; Atamba M.A. Res. J. Chem. Environ. 2008, $12,87$. 